\title{
Double whammy: a tale of two malignancies
}

\author{
Abhishek Sharma, ${ }^{1}$ Paul Devakar Yesudian ${ }^{2}$
}

${ }^{1}$ Department of Medicine, Cardiff University, Cardiff, UK ${ }^{2}$ Dermatology Department, Wrexham Maelor Hospital, Wrexham, UK

\section{Correspondence to}

Abhishek Sharma, sharmaa33@cardiff.ac.uk

Accepted 7 July 2017

\section{(1) \\ CrossMark}

\section{To cite: Sharma $A$} Yesudian PD. BMJ Case Rep Published Online First: [please include Day Month Year]. doi:10.1136/bcr-2017 221148

\section{DESCRIPTION}

A 61-year-old woman was referred to the dermatology clinic with multiple skin lesions on her scalp and central back. They were relatively asymptomatic but had increased in size over the previous few months. Her medical history was significant as she had a cerebellar medulloblastoma when she was 19 years old that was treated with a 6 -month course of radiotherapy on her scalp and along the spinal cord.

On examination, she had multiple erythematous scaly plaques on the right occipital scalp and lower back, consistent with superficial basal cell carcinomas (BCC) and a nodular BCC in the left occipital scalp. They were present within the areas previously treated with radiotherapy, arising from the skin that showed poikilodermatous (atrophic) changes (figures 1 and 2). Scarring alopecia from the previous radiotherapy was also prominent in the occipital scalp. A diagnosis of postradiotherapy BCCs was made. In the last 6 years, her superficial BCCs have been treated successfully with topical 5 -fluorouracil and topical imiquimod. Three nodular BCCs have been surgically excised. Our patient remains under surveillance every 4 months.

BCC are the most common cancers in the world, occurring mainly in the sun-exposed areas of the head and neck. They present as pearly erythematous papules or nodules with surface telangiectasia. ${ }^{1}$ Exposure to ultraviolet light, particularly sunburns during childhood and adolescence, is accepted as the most important aetiological factor. Treatment with ionising radiation, which was widely used for tinea capitis prior to the advent of oral antifungals in the 1950 s and is currently used to treat various skin and subcutaneous cancers, has also been linked with BCC formation. Postradiotherapy BCCs are one of the most common chronic complications of this treatment, which develops on average 20 years after exposure. An increased risk has been noted with younger age of exposure; more severe

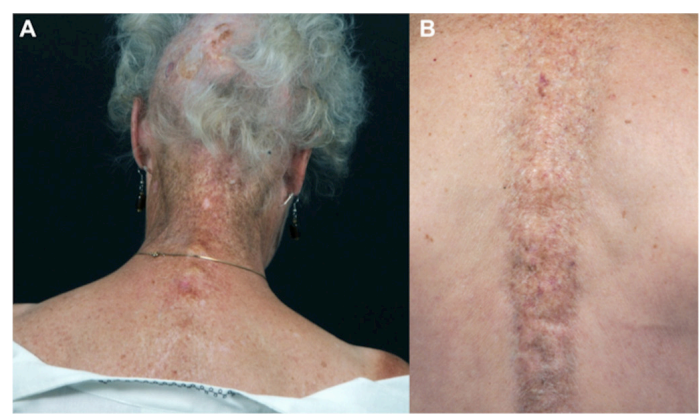

Figure 1 Poikilodermatous postradiotherapy changes in the scalp, nape of neck (A) and along the spinal cord (B).

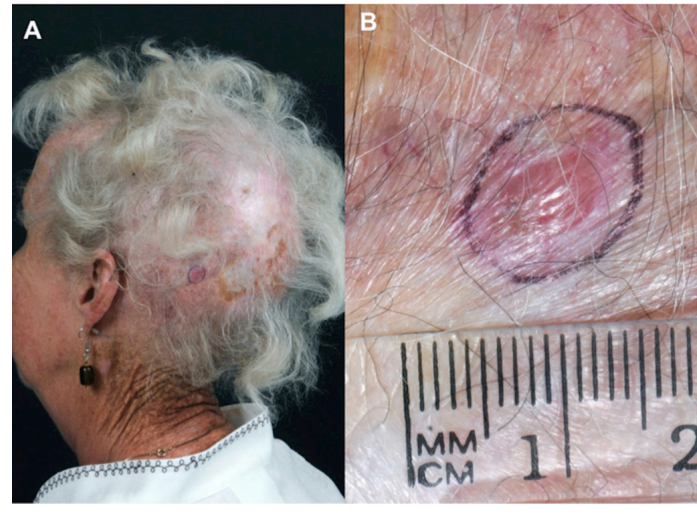

Figure 2 Postradiotherapy scarring alopecia with a BCC in the left occipital scalp (A); closer view of the nodular BCC (B). BCC, basal cell carcinoma.

radiodermatitis was associated with a higher prevalence of skin cancers. BCCs developing in irradiated skin tend to be more aggressive and have an increased propensity for recurrence. ${ }^{2}$ There is a pronounced rate of additional skin cancers once the first BCC has occurred. The exact cause of this increase in skin sensitivity to radiation and resulting non-melanoma skin cancer formation is still unknown. Due to its low metastatic potential, the management of BCCs focuses on local control. Treatment with surgical excision is the gold standard, but alternative choices, particularly for the superficial variant, include topical 5 -fluorouracil, topical imiquimod, cryotherapy and photodynamic therapy. Avoidance of excessive sun exposure and sun burns is essential in preventing the formation of new tumours.

Contributors AS and PDY: certify that they have participated sufficiently in the work to take public responsibility for the content, including participation in the concept, design, analysis, writing or revision of the manuscript; and contributed to the drafting of the manuscript, revising of the manuscript and approval of the version of the manuscript to be published.

Competing interests None declared.

Patient consent Obtained.

\section{Learning points}

- Long-term supervision of patients following radiotherapy is recommended due to an increased risk of developing multiple basal cell carcinomas on average 20 years post radiotherapy.

- Following radiotherapy, patients need to be educated about the occurrence of basal cell carcinomas and the importance of surveillance for new lesions. 
Provenance and peer review Not commissioned; externally peer reviewed.

(c) BMJ Publishing Group Ltd (unless otherwise stated in the text of the article) 2017. All rights reserved. No commercial use is permitted unless otherwise expressly granted.

\section{REFERENCES}

1 Rubin Al, Chen EH, Ratner D. Basal-cell carcinoma. N Engl J Med 2005;353:2262-9. 2 Li C, Athar M. lonizing Radiation Exposure and Basal Cell Carcinoma Pathogenesis. Radiat Res 2016;185:217-28.

Copyright 2017 BMJ Publishing Group. All rights reserved. For permission to reuse any of this content visit http://group.bmj.com/group/rights-licensing/permissions.

BMJ Case Report Fellows may re-use this article for personal use and teaching without any further permission.

Become a Fellow of BMJ Case Reports today and you can:

- Submit as many cases as you like

- Enjoy fast sympathetic peer review and rapid publication of accepted articles

- Access all the published articles

- Re-use any of the published material for personal use and teaching without further permission

For information on Institutional Fellowships contact consortiasales@bmjgroup.com

Visit casereports.bmj.com for more articles like this and to become a Fellow 